\title{
Determination of Some Physico-Chemical Parameters and Water Quality Index (WQI) of Laguna de Bay, Philippines
}

\author{
Jessa Marie S. Caabay ${ }^{12}$ \\ ${ }^{1}$ Faculty, College of Sciences, Palawan State University \\ Puerto Princesa City, Palawan, Philippines \\ ${ }^{2}$ Graduate Student, Institute of Environmental Science and Meteorology, College of Sciences \\ University of the Philippines, Diliman
}

\begin{abstract}
Water quality monitoring activities is a vital part in assessing the status of certain bodies of water such as the Laguna de Bay. The lake has been a significant natural resource as a catchment of an expansive watershed providing various ecological and economic values. It is the largest inland waterbody in the Philippines and the third largest in South East Asia. Water quality monitoring network is a critical element in the assessment, restoration and protection of Laguna de Bay. This paper measured some important physicochemical properties of four selected sites from Laguna de Bay such as temperature, $\mathrm{pH}$, electrical conductivity, alkalinity, dissolved oxygen levels, and phosphate and ammonia concentrations. Water Quality Index (WQI) utilizing Weighted Arithmetic Water Quality Index Method was also evaluated.
\end{abstract}

Keywords- Water Quality Index, Laguna de Bay, Physico-Chemical Parameters

\section{INTRODUCTION}

Water quality is a measure of the condition of a certain water body pertaining to its physical, chemical, radiological, and biological characteristics. Environmental water quality or the ambient water quality refers to that of the surface waters that can vary significantly as a result of different environmental conditions, ecosystems, and intended human uses (Simeonov et al., 2003). The quality of surface water and problems on water pollution has been a rampant issue worldwide. Natural processes and anthropogenic influences such as urban, industrial and agricultural activities have caused great impacts, as such, water quality has been an essential part of environ mental monitoring.

Laguna de Bay is the third largest inland water body in the South East Asia and the largest in the Philippines. Approximately, it has a surface area of $900 \mathrm{~km}^{2}$, an elevation of about 1 meter above sea level and an average depth of 2.5 meters. Laguna borders the lake in the east, west, and southwest, the province of Rizal in the north to northeast, and Metro Manila in the northwest. Twenty-one major rivers and more than three times as many smaller tributaries drain towards the lake, then having one outlet, the Napindan-Pasig river, connecting to the to Manila Bay (Tamayo- Zafaralla et al., 2010). Laguna de Bay is comprised of four bays, the East Bay, Central Bay, and West Bay that converge at the South Bay. The West Bay watershed is considered as the most populated characterized by highly developed areas. The East Bay on the other hand is the least developed. The West and Central Bays are separated by Talim Island, which is the biggest and most populated island within the Laguna de Bay (Israel, 2007).

At present, one of the most important uses of the lake is for fishing and aquaculture for fish production, it also serves as source of water for irrigation, industry, and livestock production. Laguna de Bay is also being utilized for navigation, flood control, and for recreation and aesthetic purposes, all greatly contributing to the lake's water quality (Barril\&Tumlos, 2002). In the past years, several studies showed its water quality is deteriorating and the ecology of the lake is extremely disturbed. Some of the problems that were reported include pollution (biochemical oxygen demand, heavy metals in water and sediment), siltation, perennial turbidity, eutrophication, declining alkalinity, fungal fish disease, declining fish yield, impaired biodiversity. It was also noted that about a hundred different pollutants flow into the lake and its tributaries. The degradation of water quality has resulted in altered species composition and decreased the overall health of aquatic 
communities within the basin. The lake is an extremely stressed ecosystem needing rehabilitation (TamayoZafaralla et al., 2010). Because of the alarming issues regarding the state of Laguna de bay, programs and projects aiming to rehabilitate the lake were established. The development of water quality monitoring network is a critical element in the assessment, restoration and protection of Laguna de Bay. To provide a better understanding of the current ecosystem health, this study was conducted as part of the monitoring activities of the water quality status of Laguna de Bay aiming to analyze the some physico-chemical parameters such as dis solved oxygen level, temperature, $\mathrm{pH}$, electrical conductivity, alkalinity, and nutrients such as phosphate and ammonia. Using the said parameter, the Water Quality Index (WQI) was also computed as a basis of the status of the lake.

\section{MA TERIALS AND METHODS}

\subsection{Study Site}

Laguna de Bay is situated in the middle part of Luzon bordering the capital region of Metro Manila and the provinces of Rizal and Laguna. With a total watershed area of 292,000 hectares having around 100 rivers and streams draining into it. The entire watershed spans 14 cities and 47 municipalities located in the provinces of Rizal, Laguna, Cavite, Batangas, Quezon, and Metro Manila. Laguna de Bay itself is comprised of four bays: east bay, central bay, west bay and south bay and it drains its water into Manila Bay through the Pasig River, the maximum depth is located at Diablo Pass of about 20 meters. It has an average water volume of 2.25 billion cubic meters and length of coastline of 285 kilometers. The numerous resources found in the lake include fish, mollusks, crustaceans, and other plant and animal. Moreover, Laguna de bay has several economic uses that include business, transportation, electricity, industrial cooling, agriculture, recreation and as floodwater reservoir (Israel, 2007).

Four different sampling sites were selected as the stations were the water sampling procedure (Figure 1). Site 1 (Binangonan, Rizal with Latitude: 14.48916, Longitude: 121.1386), Site 2 (NAPOCOR with Latitude: 14.41718, Longitude: 121.1746) and Site 3 (San Pedro, Laguna, with Latitude: 14.37032, Longitude: 121.0937) are located at the West Bay, while Site 4 (Pila, Laguna, with Latitude: 14.27657, Longitude : 121.353) is located at the East Bay.

Figure 1

Four S ampling Sites at the Laguna de Bay

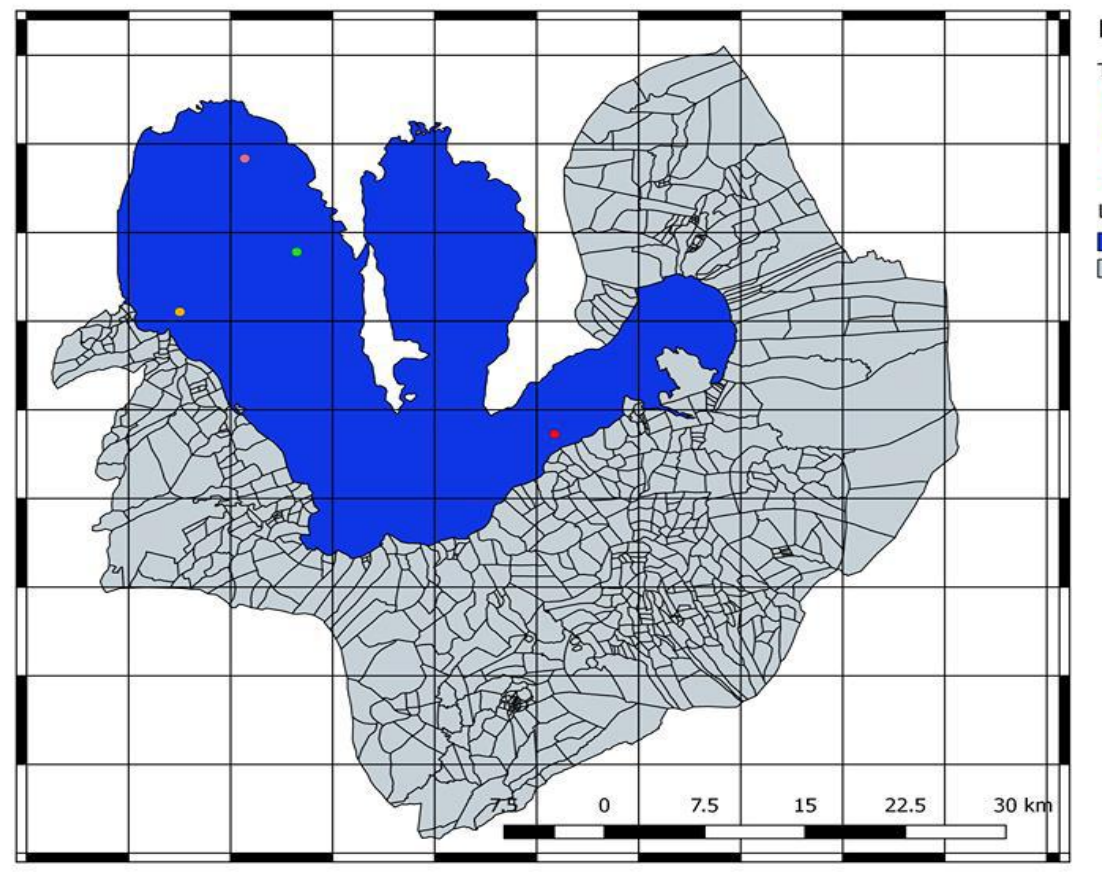

Legend

Temporary OSite 1 (Binangonan)

- Static O Site 2 (NAPOCOR)

- Static Site 3 (San Pedro, Laguna)

- Site 4 (Pila, Laguna)

Laguna Pr $\bigcirc$ Site 4 (Pila, Laguna) . . . .)

Laguna lake

Laguna Province

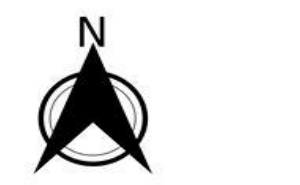

Province of

Laguna 


\section{Test Parameters and Sampling Procedures}

Standard methods were observed and followed for the sampling procedures in all of the four study sites. Surface waters from the said sites were collected and placed in appropriate water bottles. An additional bottom water was collected from Site 1 and 3 (NAPOCOR and San Pedro, Laguna Sites). Unstable parameters such as temperature, electrical conductivity (EC), $\mathrm{pH}$, and dissolved oxygen (DO) were measured at each of the sampling site using a multicenter. Samples were brought and stored at the Environmental Pollution Studies Laboratory (EPSL) of the Institute of Environmental Science (IESM) of the University of the Philippines Diliman for analysis of other physico-chemical parameters such alkalinity and dissolved oxygen level (DO), and nutrient levels of phosphate and ammonia. Alkalinity and dissolved oxygen levels were measured using the titrimetric, Winkler Azide modification method. Phos phate was measured using HI 717 Phosphate High Range Meter while Ammonia-Nitogen was obtained utilizing the HI 715 A mmonia Medium Range Meter.

\subsection{Data Analysis}

Using different parameters such as dissolved oxygen level, temperature, $\mathrm{pH}$, electrical conductivity, alkalinity, and nutrients (phosphate and ammonia), the water quality index of each of the stations were calculated. The Weighted Arithmetic Water Quality Index Method (WAWQI) was used for the calculation of water quality index (Qu reshimatva et al., 2015) using the formula:

$\mathrm{WQI}=\mathrm{qnWn} / \Sigma \mathrm{Wn}$;

$\mathrm{qn}=100(\mathrm{Vn}-\mathrm{V} 10) /(\mathrm{S}-\mathrm{V} 10)$

Where:

$\mathrm{qn}=$ Quality rating for the nth water quality parameter

$\mathrm{Wn}=$ Unit weight for $\mathrm{nth}$ water quality parameter

$\mathrm{Vn}=$ Estimated value of the nth water quality parameters of collected sample

$\mathrm{Sn}=$ Standard permissible value of the nth water quality parameter

$\mathrm{V} 10=$ Ideal value of the nth water quality parameter in pure water

The water quality index was then evaluated using the table below prescribed by Chaterjee \& Raziuddin (2002) and Thakoret al.(2011).

Table 1

Water Quality Index and Status

\begin{tabular}{|c|c|}
\hline Water Quality Index & Water Quality Status \\
\hline $0-25$ & Excellent \\
\hline $26-50$ & Good \\
\hline $51-75$ & Poor \\
\hline $76-100$ & Very Poor \\
\hline
\end{tabular}

(Source: Chaterjee \& Raziuddin (2002) and Thakor et al. (2011)

\section{RES ULTS AND DISCUSS IONS}

Spatial and temporal variations in the water chemistry is unavoidable due to contributions of several factors, as such, this water quality sampling procedures were conducted for an additional data for the monthly water quality monitoring of four selected stations at the Laguna de Bay. Some physico-chemical properties from the water samples from the four different sites were analyzed and the results were tabulated below: 
Table 2

Physicochemical Properties of Water Samples From the Four Sites

\begin{tabular}{|l|c|c|c|c|c|c|c|c|}
\hline \multicolumn{1}{|c|}{ Location } & $\begin{array}{c}\text { T } \\
\mathbf{(} \mathbf{C})\end{array}$ & $\mathbf{p H}$ & $\mathbf{E C}$ & $\begin{array}{c}\text { In situ } \\
\mathbf{D O}\end{array}$ & $\mathbf{D O}$ & $\begin{array}{c}\text { TA } \\
(\mathbf{m g} \\
\mathbf{C a C O 3 / L )}\end{array}$ & $\begin{array}{c}\text { PO } \\
(\mathbf{p p m})\end{array}$ & $\begin{array}{c}\text { Ammonia } \\
(\mathbf{p p m})\end{array}$ \\
\hline Site 1 (Binangonan, Rizal) & 30.4 & 7.92 & 0.475 & 9.65 & 12.45 & 88 & 0.6 & 0.02 \\
\hline Site 2 (NAPOCOR) & 30.75 & 5.31 & 0.48 & 6.485 & $\begin{array}{c}{ }^{\mathrm{a}} 9.4 \\
\mathrm{~b}\end{array}$ & 100 & 0.1 & 0.02 \\
\hline Site 3 (San Pedro, Laguna) & 29.75 & 6.11 & 0.455 & 6.235 & 10.2 & 92 & $\begin{array}{c}\mathrm{a} 0.6 \\
\mathrm{~b} 0.1\end{array}$ & $\begin{array}{c}\mathrm{a}: 0 \\
\mathrm{~b} 0.34\end{array}$ \\
\hline Site 4 (Pila, Laguna & 28.1 & 5.485 & 0.41 & 6.195 & 10 & 88 & 0.3 & 0.02 \\
\hline
\end{tabular}

${ }^{\mathrm{a}}$ surface; ${ }^{\mathrm{b}}$ bottom

T- Temperature; EC- Electrical Conductivity;TA-Toatal alkalinity; $\mathrm{PO}_{4^{-}}$Phosphate

Laguna de Bay is classified under the Class C for the Water Body Classification and Usage of Freshwater of the DENR Administrative Order No. 2018-08, with intended beneficial uses as fishery water for the propagation and growth of fish and other aquatic sources. It also falls under the Recreational water class II intended for boating and fishing or similar activities and for agriculture, irrigation and livestock watering. The temperature of the surface waters from the four sites ranges from 28.1 to 30.75 , which according to the guidelines is still within the limit $\left(25^{\circ} \mathrm{C}-31^{\circ} \mathrm{C}\right)$. The differences in the surface water temperature may have been affected by the time sampling time and the weather within the day. For the $\mathrm{pH}$ levels, the three sites either exceeded or did not reach the limit which is 6.5 to 9.0. Only the water samples from Site 1 with pH of 7.92 are within the guidelines. The $\mathrm{pH}$ of water may have been affected by other chemical components and nutrients of the surface water. Polluted natural waters are recorded to have $\mathrm{pH}$ values lower or higher than 7 based on the nature of pollutants (Ouyang, 2005). It is important for the biotic communities as most of the plant and animal species can survive in narrow range of $\mathrm{pH}$ from slightly acidic to slightly alkaline condition. On the other hand, the electrical conductivity of the samples ranges from 0.41 to 0.48 . Electrical conductivity or the conductance of water refers to it capacity to transmit electric current and it serves to as sess the purity of water depend ing on the presence of ions as well as their mobility, their relatrive and total concentration, mobility, and temperature of measurement. Electrical conductivity is also affected by temperature, its value increases by 2 to $3 \%$ per $10 \mathrm{C}$ (Oyem et al., 2014) and most dissolved inorganic substances in the ionized form in the water contribute to the conductance.

Dissolved oxygen is as an indicator of the physical, chemical and biological activities of the water body. For the dissolved oxygen (DO) levels of the surface waters, it is observed that the ones measured in the laboratory is higher than that of the DO levels in situ, this might be attributed to some errors since, there is no standard KH (IO3)2 used during the titration method. Nevertheless, both methods, showed that Site 1 has the highest DO level and the bottom water from Site 3 showed the least DO level as expected since it is where most of the anaerobic decomposition of organic matter takes place. The DO levels are higher than that stated in the guidelines which is $5 \mathrm{mg} / \mathrm{L}$. The reported DO levels were daytime levels, which, due to photosynthetic activity and well-mixed nature off the lake, are expected to be high (Barril\&Tumlos, 2002). Two main sources are diffusion of oxygen from the air and photos ynthetic activity. Diffusion from air depends on solubility of oxygen, water movement, temperature, salinity and other factors.

The alkalinity of the water samples ranges from 88 to 100 . Alkalinity is a measure of capacity of water to neutralize a strong acid, is a function of carbonate, hydroxide content, and includes the contributions from borates, phosphates, silicates and other bases (Qureshimatva et al., 2015). For the nutrient levels, based on the DAO guidelines, phosphates for Class C waters is $0.5 \mathrm{mg} / \mathrm{L}$. Surface waters from Sites 1 (Binangonan) and 3 (San Pedro) slightly exceeded by $0.1 \mathrm{mg} / \mathrm{L}$ while the other 2 samples are within the guidelines. Phos phates come from agricultural runoff, animal waste and sewage that might have affected the two sites. Ammonia from the samples on the other hand are within the limit which is $0.05 \mathrm{mg} / \mathrm{L}$, but the bottom water from Site 3 (San Pedro, Laguna) is a bit higher that may be attributed to the decomposition of organic matters.

The Water Quality Index (WQI) of Laguna de Bay from the selected stations was calculated from the different physicochemical parameters. The values of various physicochemical parameters for calculation of water quality index are presented in Table 3 while the obtained WQI is presented in Table 4. 
Table 3

Calculation for the Water Quality Index (W QI) for the Four Sites

\begin{tabular}{|c|c|c|c|c|c|c|c|}
\hline SITES & Parameters & Observed & $\begin{array}{c}\text { Guideline } \\
\text { Values } \\
\text { (DAO No. 2016-08) }\end{array}$ & $\begin{array}{c}\text { Unit } \\
\text { weight } \\
(\text { Wn })\end{array}$ & $\begin{array}{l}\text { Ideal Value } \\
\text { (V10) }\end{array}$ & $\begin{array}{c}\text { Quality Rating } \\
\text { (Qn) }\end{array}$ & Qn*Wn \\
\hline \multirow{8}{*}{$\begin{array}{l}\text { SITE 1 } \\
\text { Binangonan, } \\
\text { Rizal }\end{array}$} & $\mathrm{pH}$ & 7.92 & 7.5 & 0.1333 & 7 & 184 & 24.53333 \\
\hline & EC & 0.475 & $300^{*}$ & 0.0033 & 0 & 0.158333 & 0.000528 \\
\hline & In Situ DO & 9.65 & 5 & 0.2 & 14.6 & 51.5625 & 10.3125 \\
\hline & $\mathrm{DO}$ & 12.45 & 5 & 0.2 & 14.6 & 22.39583 & 4.479167 \\
\hline & $\begin{array}{l}\text { Total } \\
\text { Alkalinity }\end{array}$ & 88 & $120 *$ & 0.0083 & 0 & 73.33333 & 0.611111 \\
\hline & Phosphate & 0.6 & 0.5 & 2 & 0 & 120 & 240 \\
\hline & Ammonia & 0.02 & 0.05 & 20 & 0 & 40 & 800 \\
\hline & \multicolumn{3}{|l|}{ TOTAL } & \multicolumn{2}{|l|}{22.545} & 491.45 & 1079.937 \\
\hline \multirow{8}{*}{$\begin{array}{l}\text { SITE 2 } \\
\text { NAPOCOR }\end{array}$} & $\mathrm{pH}$ & 5.31 & 7.5 & 0.1333 & 7 & -338 & -45.0667 \\
\hline & EC & 0.48 & $300^{*}$ & 0.0033 & 0 & 0.16 & 0.000533 \\
\hline & In Situ DO & 6.485 & 5 & 0.2 & 14.6 & 84.53125 & 16.90625 \\
\hline & $\mathrm{DO}$ & 9.4 & 5 & 0.2 & 14.6 & 54.16667 & 10.83333 \\
\hline & $\begin{array}{l}\text { Total } \\
\text { Alkalinity }\end{array}$ & 100 & $120 *$ & 0.0083 & 0 & 83.33333 & 0.694444 \\
\hline & Phosphate & 0.1 & 0.5 & 2 & 0 & 20 & 40 \\
\hline & Ammonia & 0.02 & 0.05 & 20 & 0 & 40 & 800 \\
\hline & \multicolumn{3}{|l|}{ TOTAL } & \multicolumn{2}{|l|}{22.545} & -55.8088 & 823.3679 \\
\hline \multirow{8}{*}{$\begin{array}{l}\text { SITE } 3 \\
\text { San Pedro, } \\
\text { Laguna }\end{array}$} & $\mathrm{pH}$ & 6.11 & 7.5 & 0.1333 & 7 & -178 & -23.7333 \\
\hline & $\mathrm{EC}$ & 0.455 & $300^{*}$ & 0.0033 & 0 & 0.151667 & 0.000506 \\
\hline & In Situ DO & 6.235 & 5 & 0.2 & 14.6 & 87.13542 & 17.42708 \\
\hline & DO & 10.2 & 5 & 0.2 & 14.6 & 45.83333 & 9.166667 \\
\hline & $\begin{array}{l}\text { Total } \\
\text { Alkalinity }\end{array}$ & 92 & $120 *$ & 0.0083 & 0 & 76.66667 & 0.638889 \\
\hline & Phosphate & 0.6 & 0.5 & 2 & 0 & 120 & 240 \\
\hline & Ammonia & 0 & 0.05 & 20 & 0 & 0 & 0 \\
\hline & \multicolumn{3}{|l|}{ TOTAL } & \multicolumn{2}{|l|}{22.545} & 151.7871 & 243.4998 \\
\hline \multirow{8}{*}{$\begin{array}{l}\text { SITE 4 } \\
\text { Pila, } \\
\text { Laguna }\end{array}$} & $\mathrm{pH}$ & 5.485 & 7.5 & 0.1333 & 7 & -303 & -40.4 \\
\hline & $\mathrm{EC}$ & 0.41 & $300^{*}$ & 0.0033 & 0 & 0.136667 & 0.000456 \\
\hline & In Situ DO & 6.195 & 5 & 0.2 & 14.6 & 87.55208 & 17.51042 \\
\hline & $\mathrm{DO}$ & 10 & 5 & 0.2 & 14.6 & 47.91667 & 9.583333 \\
\hline & $\begin{array}{l}\text { Total } \\
\text { Alkalinity }\end{array}$ & 88 & 120 & 0.0083 & 0 & 73.33333 & 0.611111 \\
\hline & Phosphate & 0.3 & 0.5 & 2 & 0 & 60 & 120 \\
\hline & Ammonia & 0.02 & 0.05 & 20 & 0 & 40 & 800 \\
\hline & \multicolumn{3}{|l|}{ TOTAL } & \multicolumn{2}{|l|}{22.545} & 5.93875 & 907.3053 \\
\hline
\end{tabular}

*Qureshimatva et al., (2015)

Table 4

Water Quality Status of the Four (4) Sites based on the Computed Water Quality Index (WQI).

\begin{tabular}{|l|c|c|}
\hline Location & Water Quality Index (WQI) & Water Quality Index* \\
\hline Site 1 (Binangonan,Rizal) & 47.90 & Good \\
\hline Site 2 (NAPOCOR) & 36.52 & Good \\
\hline Site 3 (San Pedro, Laguna) & 10.80 & Excellent \\
\hline Site 4 (Pila, Laguna) & 40.24 & Good \\
\hline
\end{tabular}

*Chaterjee\&Raziuddin (2002) and Thakor et al.(2011)

Based on the different parameters, the water quality index of each of the samples was computed and it was observed that the three sites (Binangonan, NAPOCOR, and Pila) obtained WQI that is rated as good while water samples from San Pedro, Laguna is marked as having an excellent quality of water. Site 1 (Binangonan, Rizal), Site 2 (NAPOCOR) and Site 3 (San Pedro, Laguna) are located at the West Bay, while Site 4 (Pila, Laguna) is located at the East Bay. Individually, almost all of the physic-chemical parameters measured were within the guideline values for Class $C$ waters. The quality of the surface waters from site 3 could be attributed to the nutrient levels detected since no amount of ammonia was traced. Relatively, the results could have been rated as Site 1 having the least quality of water while site 3 will have a good water quality, but the results of this study is different from that of the various water monitoring in the lake over the years. It was reported that water quality of the Bay may have shown some improvement over the years from the different rehabilitation and restoration projects, but the water quality is still not in an excellent condition (Is rael, 2007). 
In this paper, it was presented that WQI could be calculated using different physico chemical properties of water. W QI obtained from Weighted Arith metic Water Quality Index Method (WAWQI) could be used as a tool in assessing water quality status of a certain body of water.

\section{Conclusions}

Physico-chemical water properties are among the different measures of water quality. It is one of the commonly used methods in order top assess the current status of surface waters and other bodies of waters. In this study, it was found out that the temperature of the surface waters from the four sites ranges from 28.1 to 30.75 , which is still with in the limit $\left(25^{\circ} \mathrm{C}-31^{\circ} \mathrm{C}\right)$. For $\mathrm{pH}$, only the water samples from Site 1 (7.92) are within the guidelines. On the other hand, the electrical conductivity ranges from 0.41 to 0.48 . For the DO, Site 1 has the highest and the bottom water from Site 3 showed the least as expected since it is where most of the anaerobic decomposition of organic matter takes place. The DO levels are higher than that of the guideline values $(5 \mathrm{mg} / \mathrm{L})$. The alkalinity of the water samples ranges from 88 to 100 , which is lower than the guideline value of 120. For the nutrient levels, phosphates of the surface waters from Sites 1 and 3 slightly exceeded by 0.1 $\mathrm{mg} / \mathrm{L}$ while the other 2 samples are within the guidelines while ammonia from the samples are within the limit which is $0.05 \mathrm{mg} / \mathrm{L}$, but the bottom water from Site 3 (San Pedro, Laguna) is a bit higher that may be attributed to the decomposition of organic matters. Based on the different parameters, the water quality index showed that the three sites (Binangonan, NAPOCOR, and Pila) obtained WQI that is rated as good while water samples from San Pedro, Laguna is marked as having an excellent quality of water, but the results is opposite of the reports of the monitoring activities. The status and water quality of the water ias a result of different factors that had contributed to the ambient water quality. The ambient water quality of Laguna de Bay must always be monitored since the Bay is being used for various purposes.

\section{AC KNOW LEDGMENT}

This study was carried out as part of a special problem of the author for the graduate degree in Environmental Science at the University of the Philippines Diliman. Data collection and analysis were conducted for the Water Quality Sampling Techniquesclass. The author acknowledges the support of the Environmental Pollution Studies Laboratory (EPSL), the Institute of Environmental Science (IESM) of the University of the Philippines Diliman, and the Laguna Lake Development Authority (LLDA). The author is also grateful to Prof. Mylene G. Cayetano and Prof. Carlos Primo C. David who handled and spearheaded the class toconduct the study.

\section{REFERENCES}

[1] Barril,C. \&T umlos,E.T. (2002) Water quality trends and trophic state assessment of Laguna de Bay, Philippines, Aquatic Ecosystem Health \& Management, 5:2,115-126, DOI: 10.1080/14634980290031811.

[2] Chaterjee, C. \&Raziuddin, M. (2002) Determination of water quality index (WQI) of a degraded river in Asanol Industrial area, Raniganj, Burdwan, West Bengal. Nat ure Environment and Pollution Technology 2:181-189.

[3] DAO no. 2016-08, water quality guidelines and General effluent standards of 2016.

[4] Israel, D. C. (2007).Fishpen and Fishcage Culture in Laguna de Bay: Status, Economic Importance, and the Relative Severity of Problems Affect ing itsPractice. Philippine Journal of Development, 35(1), 55.

[5] Oyem, H.H., Oyem, I.M., \&Ezeweali. (2014). Temperat ure, pH, Electrical Conductivity, Total Dissolved Solids and Chemical Oxygen Demand of Groundwater in Boji-BojiAgbor/Owa Area and Immediate Suburbs. Research Journal of Environmental Sciences 8(8): 444-450.

[6] Ouyang, Y. (2005). Evaluation of river water quality monitoring stations by principal component analysis. Water research, 39(12), 2621-2635.

[7] Qureshimatya,U.M., Maurya, R.R., Gamit, S.B. , Patel, R.D. and Solanki HA. (2014). Determination of Phy sico -Chemical Parameters and water quality index (WQI) of Chandlodia Lake, Ahmedabad, Gujarat,India. J. Environ. Anal. Toxicology Vol 5 (4): 288.

[8] Simeonov, V., Stratis, J. A., Samara, C., Zachariadis, G., Voutsa, D., Anthemidis, A., ..\&Kouimtzis, T. (2003). Assessment of the surface water quality in Northern Greece.Water research, 37(17), 41 19-4124.

[9] Tamayo-Zafaralla,M., Santos,. R.A., Orozco, R.P., \&Elegado, G.P. ( 2010).The ecological stat us of Lake Laguna de Bay, Philippines M.

[10] Thakor FJ, Bhoi DK, Dabhi HR, Pandya SN, Chauhan NB (2011) Water Quality Index (WQI) of Pariyej lake District Kheda, Gujarat. Current World Environment 6: 225-231. 